\title{
Professionalism: The privilege and burden of self-regulation
}

$\mathrm{S}$ elf-regulation is a basic tenet of all professions, and few professions value that principle as much as the field of medicine. But in today's world - where people are more skeptical of expertise, where conflicts of interest abound in medicine, where the public demands greater transparency from all professions, where news of a medical scandal can twitter around the entire earth in seconds - granting doctors complete control over their own ship is becoming a tougher sell.

"Self-regulation was originally instituted at the request of the medical profession because the body of knowledge in the profession was esoteric and unknown to the average citizen, and it would be difficult for external regulation to be as effective," says Dr. Richard Cruess, a professor of surgery at McGill University's Centre for Medical Education in Montréal, Quebec. "But it was linked to the belief that the medical profession was altruistic."

The problem with this collegial form of regulation, however, is that professions tend to be protective of their members. This is not really that surprising; individuals belonging to any group tend to be protective of their own kind.

In medicine, historically, only the most egregious of professional lapses were considered worthy of a reprisal greater than a wrist slap. "Gross negligence would be punished, but a lot of small stuff got swept under the carpet," says Cruess.

The need for external input may explain, in part, why the governing councils of provincial colleges of medicine increasingly are compelled to have nonphysician members. The presence of nonexperts, after all, theoretically prevents members of a profession from speaking purely in their own language or acting strictly in the interests of the tribe. It helps keep an insular group connected to the public they serve. Though this is important, most doctors would be quick to point out there is still

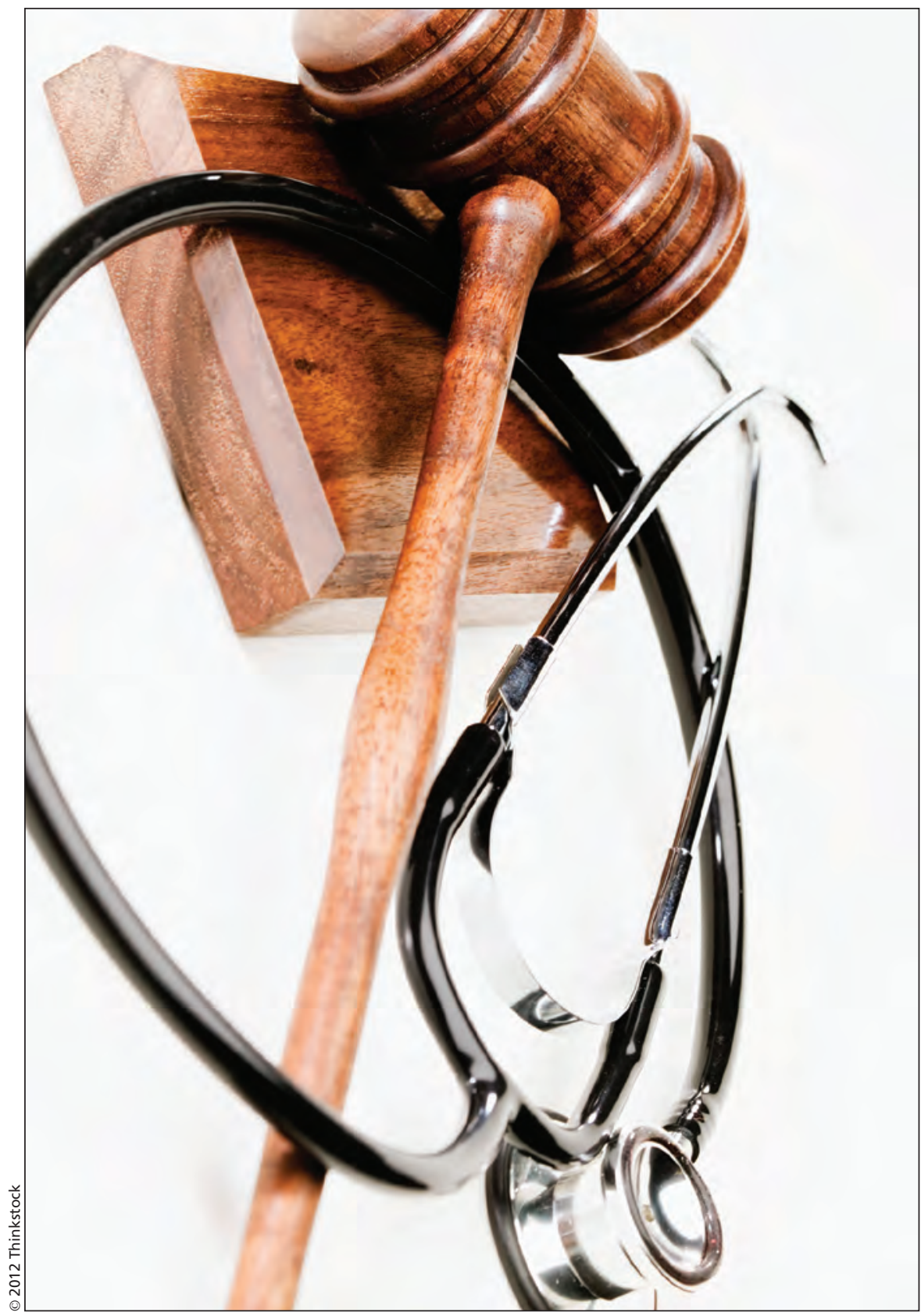

The privilege of professional autonomy comes with a responsibility to keep your house in order, experts say.

no substitute for technical expertise in the regulation process.

"There may be other things that we need to complement it, but we can't move away from self-regulation," says Dr. Sharon Johnston, assistant professor of family medicine at the Univer- sity of Ottawa in Ontario. "I don't think there is anything that can effectively replace it, given the nature of medical care."

But the privilege of professional autonomy comes with a responsibility to keep your house in order. One way 
to do that, Johnston has suggested, is for the medical profession to make a greater effort to understand the causes of disciplinary actions against physicians and find ways to reduce the behaviours that lead to them (Open Med 2011;5:e166-e172).

"The right and obligation of selfregulation is designed to serve and protect patients," wrote Johnston. "It is a privilege and a burden shared by all physicians and must be supported by all members of the profession."

Another way that physicians can build the public trust needed for selfregulation to work is to do a better job of monitoring the quality of the care they provide. Often, however, physicians resist revalidation policies that require them to collect data, claiming it's too demanding or expensive or that it detracts from patient care - even though, basically, it's just about "demonstrating that you are capable of doing what you are supposed to be doing," says Dr. Donald Irvine, chairman of Picker Institute Europe, a nonprofit that promotes public health and medical education, and past president of the United Kingdom's national medical regulator, the General Medical Council.

"If you are going to offer a level of consistent care, you do need to be vigorous about collection of data on performance," says Irvine. "Recording your results accurately is part and parcel of being an effective doctor. They should be analyzed and reflected back at you, and put in a constructive form of appraisal. Aviators could have told you that 30 years ago."

Without data reflecting performance, the competency and behaviour of a physician may merely be assumed to be sufficient. Or perhaps a fear of losing the regard of one's peers is enough to set a wayward doctor back onto the right path. But what if an individual is impervious to peer pressure? And what if nobody, peer or otherwise, is keeping an eye on those individuals?

"A lot of problematic doctors are able to practise for a long time without being supervised or checked, and this can lead to these horrendous scandals erupting," says Mary Dixon-Woods, professor of medical sociology at the
University of Leicester in the United Kingdom.

Public outrage over medical scandals in the UK over the past decade is, in fact, one of the primary reasons the profession is no longer a self-regulating one in the country. And physician members no longer outnumber lay members on the General Medical Council.

"Though sufficient to ensure that most doctors were 'good,' the collegial model adopted by the profession left it fatally vulnerable to the problem of 'bad apples': those unwilling, incapable or indifferent to delivering on their professional commitments and who betrayed the trust of both patients and peers," Dixon-Woods and colleagues wrote in a paper explaining why UK medicine in no longer self-regulating (Soc Sci Med 2011;73:1452-9). "Weak administrative systems in the NHS failed to compensate for the defects of the collegium in controlling these individuals. The scandals both provoked and legitimised erosion of the profession's self-regulatory power."

When multiple medical scandals come to light, it can be an indicator that the medical profession is putting its own interests - namely, protecting its reputation - above that of the public. "All social groups create their own social rules," says Justin Waring, a pro- fessor of organizational behaviour at Nottingham University Business School in the UK. "One of the problems was that medicine was out of step with what society wanted."

Pressure from UK society to reform how medicine was governed has altered a regulatory structure that had stood largely unchanged for 150 years, Waring and colleagues have noted $(J$ Health Organ Manag 2010;24:54055). "Its regulatory form has mutated from one of state-sanctioned collegial self-regulation to one of state-directed bureaucratic regulation," states the paper. "The erosion of medical selfregulation can be attributed to: the pressures of market liberalisation and new public management reforms; changing ideologies and public attitudes towards expertise and risk; and high profile public failures involving doctors."

Yet, however a country regulates its medical profession, it will remain a tough and complex job, says Cruess, and will always require the involvement, in some form, of physicians. "Medicine will remain a difficult field to regulate no matter who is doing it, but it will have to rely on expert opinion." - Roger Collier, CMAJ

\section{CMAJ 2012. DOI:10.1503/cmaj.109-4286}

Editor's note: Twelfth in a multipart series on medical professionalism.

Part I: The “good doctor” discussion (www.cmaj.ca/lookup/doi/10.1503/cmaj.109-4200).

Part II: What is it? (www.cmaj.ca/lookup/doi/10.1503/cmaj.109-4211).

Part III: The historical contract (www.cmaj.ca/lookup/doi/10.1503/cmaj.109-4230).

Part IV: Can it be taught? (www.cmaj.ca/lookup/doi/10.1503/cmaj.109-4232).

Part V: Social media outreach (www.cmaj.ca/lookup/doi/10.1503/cmaj.109-4207).

Part VI: Social media mishaps (www.cmaj.ca/lookup/doi/10.1503/cmaj.109-4209).

Part VII: Logging on to tell your doctor off (www.cmaj.ca/lookup/doi/10.1503/cmaj .109-4205).

Part VIII: Assessing physician behaviour (www.cmaj.ca/lookup/doi/10.1503/cmaj $.109-4240)$.

Part IX: How payment models affect physician behaviour (www.cmaj.ca/lookup/doi /10.1503/cmaj.109-4250).

Part X: The view from outside medicine (www.cmaj.ca/lookup/doi/10.1503/cmaj .109-4257).

Part XI: The importance of trust (www.cmaj.ca/lookup/doi/10.1503/cmaj.109-4264). 